\title{
Pluralism and Deliberative Democracy
}

\section{Manlio Cinalli and Ian O'Flynn}

The term 'pluralism' features prominently in many accounts of deliberative democracy. Usually, it is taken to describe the fact that people hold different values and beliefs and hence arrive at different conclusions about how we ought to live. Accordingly, a central question in the theory of deliberative democracy is how we should respond to the fact that people not only differ but also disagree. As one might expect, deliberative democrats have offered a range of different answers to this fundamental question. We begin this chapter by discussing one such answer. As John Rawls argues, in seeking to resolve disagreements about the basic structure of a democratic society, the members of that society should appeal not to their own beliefs and values but to the sorts of political value that one might naturally expect to find inherent in the public political culture of any democratic society-equality, freedom, fairness, toleration, the rule of law etc. (Rawls 1996, 1997). As such, Rawls does not try to deal with the fact of pluralism directly through democratic deliberation. Rather, he seeks to deal with it by excluding it from the political domain. For Rawls, deliberation need not go all the way down.

While Rawls thinks that we should respond to the fact of pluralism by requiring people to couch their political arguments in terms of general political values, critics argue that his approach is too restrictive. In their view, Rawls is insufficiently sensitive to the fact that some people - for example, those with little formal education or the members of some minority ethnic, linguistic or religious groups - may struggle to express themselves in such terms (Sanders 1997; Young 2000). Rather than privileging any one mode of political argument, the critics think that the theory of deliberative democracy should incorporate a plurality of modes of political 
communication, including story-telling and singing. Our sense is that many deliberative democrats think that the critics are broadly right (e.g., Bächtiger et al. 2010). Yet the claim that some people may struggle to couch their arguments in terms of general political values is an empirical claim that has yet to be properly tested.

In the second section of this chapter, we offer a quantitative analysis of data on ethnic relations in Britain retrieved from two quality British broadsheets, The Guardian and The Times, during the course of 2007. ${ }^{1}$ Following Koopmans and Statham (1999), the coding scheme that we employ allows us to analyse the claims actors make in terms of their 'linguistic grammar' (for a more detailed discussion, see Cinalli and O'Flynn 2013). Among other attributes, we check to see whether a given claim includes a general political value and, if so, which one. While ethnic groups are precisely the sorts of actor that one might expect to struggle on this measure, our data suggest that the case against Rawls's approach is far from decisive.

'Pluralism' can also be used to refer to 'value pluralism', which is a (metaethical) theory about the nature of value itself. According to this theory, values are irreducibly plural and, in significant measure, uncombinable and incommensurable. ${ }^{2}$ Value pluralists therefore stand opposed to the view that conflicts between values can be resolved by tracing those values back to an underlying master value such as utility or by ranking them hierarchically along a single scale. Value pluralists are not relativists. On the contrary, they insist that there is a world of objective values (Berlin 1991: 11). However, they also insist that there is no 'perfect whole' or 'ultimate solution' in which all the different values might be reconciled (Berlin 1991: 13).

It is surprising that deliberative democrats have not spent more time considering the challenge that value pluralism poses to deliberative democracy. As we explain in the third section of this chapter, the truth of value pluralism would render 
deliberative democracy redundant in the face of value conflict. If values (democratic or otherwise) cannot be rationally compared, we might bargain or vote, or perhaps just resort to power. But what we cannot do is seek to convince or persuade others that our preferred values are superior to theirs.

Rather than persisting with deliberative democracy, some radical democrats think we should instead seek to cultivate a political sensibility that is capable of transforming 'antagonism' into 'agonism' (Connolly 2005; Mouffe 2002). Yet as we argue in the fourth section, before rushing to embrace radical proposals of this sort, we should first check whether the empirical evidence actually supports the truth of value pluralism. Once again, we draw on data from our research into ethnic relations in Britain. Yet this time, instead of merely coding values, we draw on network analysis to see how different values and actors relate to one another. ${ }^{3}$ As we suggest, the variable relational patterns that emerge allow us to test the combinability and commensurability of different values, and hence to assess the extent to which the empirical evidence confirms or disconfirms the truth of value pluralism.

\section{The fact of pluralism}

According to Rawls, the fact that people hold different beliefs and values is not merely a contingent and unfortunate fact about the world. Rather, it is a natural consequence of our use of reason in circumstances of freedom, particularly given the burdens of judgement (the burdens of reasoning under conditions of incomplete information, moral uncertainty and so forth). Yet since reasonable people will recognise that everyone is subject to the same burdens of judgement, Rawls thinks it 
is important to distinguish the mere fact of pluralism from the fact of reasonable pluralism (Rawls 1996: 37, 54-56, 61 and passim).

Two points should be noted here. First, the distinction between the mere fact of pluralism and the fact of reasonable pluralism enables us to see why Rawls is not a value pluralist — or, perhaps more accurately, to see why value pluralism does not figure in his account. For Rawls, value pluralism is (what he terms) a 'comprehensive doctrine'. That is, it is precisely the sort of ethical doctrine about which people can reasonably disagree and it cannot therefore provide a foundation for a just and stable democratic society. Admittedly, some commentators have not read Rawls in this way. For example, George Crowder argues that Rawls's acknowledgement of the burdens of judgement amounts to a commitment to value pluralism (Crowder 2002: 165-172; but see Jones 2006: 197-198). Yet Rawls himself did not think so_-and we think he is right not to think so, since there is no logical link between the two. Rawls seeks to explain why people disagree and does not root his explanation in any theory about the nature of value. Nor need he do so, since the burdens of judgement idea is independent of the truth or otherwise of value pluralism (see Jones 2006: 197-198). ${ }^{4}$

Secondly, the reasonableness for which Rawls argues is not part of some larger epistemological theory; although it has epistemological elements, it is not about defining the content of reasonableness per se. Rather, it is part of a broader normative understanding of what the political equality of democracy demands (Rawls 1996: 49$50,62)$. On that understanding, recognising others as equals in political argument means recognising that those others can have reasons to hold their views as firmly as we hold ours. Accordingly, if we do not make a serious effort to deliberate with them and try to find reasons that they can freely accept, we fail to treat them as political equals. This does not mean that we have to become milk-and-watery in the way in 
which we hold our views; Rawls never intended his argument for deliberative democracy to be interpreted in that way (Rawls 1996: 62-63; Jones 2003: 104-106). But it does mean that, when it comes to deciding important matters of law and policy, we should not simply insist on the truth of our own values and beliefs (although we may well believe them to be true).

Thus, on this view, arguments that people would be able to accept only if they were to become the adherents of some particular religious doctrine have no place in democratic deliberation - they have no place because they will not be generally accessible and acceptable (Rawls 1996: 62; Barry 2006: 23-24). When we make no effort to couch our arguments in terms that other people could in principle accept, or to develop our own views in ways that makes them responsive to theirs, we do not treat those with whom we disagree as equal partners in a common democratic enterprise - at best we treat them as an obstacle to be overcome (Dworkin 2006b: 132-133).

To understand why Rawls thinks that the members of a democratic society should couch their political arguments in terms of general political values, one therefore needs to understand the account of political equality with which it is bound up (Rawls 1996: 100-101; 1997:770). (For further discussion of the relationship between deliberative democracy and equality see Chapter 2 'Inequality and Democracy' by Peter McLaverty.) On that account, democratic deliberation should proceed from common ground, and Rawls thinks that that ground can be found in democratic values. For example, different religious groups might be able to share the same principle of fairness, even though each conceives of that principle as grounded in its own faith (Rawls 1996: 147). ${ }^{5}$ 
Of course, the fact that people share the same political value does not mean that political agreement will inevitably follow. Rawls accepts this much (Rawls 1996: 240). In particular, he accepts that a point may be reached when political values no longer help and we can no longer keep comprehensive doctrines out of political decision-making (Rawls 1996: 247-254; cf. Rawls 1997: 797-799). Yet while some matters will have to be resolved through the ordinary democratic process (i.e., through bargaining or log-rolling or voting), he nevertheless thinks that political values can have a vital role to play, particularly in decisions about the basic structure of society, including, for example, constitutional matters, family law or economic regulation.

Still, as we pointed out in our introductory remarks, Rawls's approach has come in for considerable criticism. One criticism that comes up repeatedly in the broader deliberative democracy literature is that, in seeking to constrain what people can and cannot say, Rawls's approach is insufficiently sensitive to the very fact of (reasonable) pluralism to which it is meant to respond. We offer an empirical assessment of that criticism in the next section.

\section{Who appeals to general political values?}

Rawls's approach is exclusive rather than inclusive. It does not try to deal with the fact of pluralism directly through democratic deliberation but instead leaves that fact in place and provides political arrangements that are independent of it. Those who criticise Rawls for 'taking the politics out of politics' are therefore broadly right: for the most party, he seeks to deal with the fact of pluralism constitutionally rather than democratically (e.g., Habermas 1998: 58). Yet the reason why he insists that people couch their arguments in terms of general political values is to ensure that political 
power is not used to impose, promote, impede, or disadvantage any part of reasonable pluralism (Rawls 1996: 217, 243). In other words, the point is to ensure that democratic deliberation will be fair, or proceed on fair terms, given the fact of pluralism.

Against this approach, critics such as Lynn Sanders and Iris Marion Young argue that what Rawls fails to see is that, through no fault of their own, some people may struggle to couch their arguments in terms of general political values (Sanders 1997: 352-353, 361; Young 2000: 56). For example, those with little formal education or those belonging to a new immigrant group may simply lack the requisite vocabulary; in the case of some linguistic minorities, the point here may be doubly true. As a result, their views may be excluded from serious consideration, not necessarily because of what they say but because of how they say it.

Neither Sanders nor Young is hostile to deliberative democracy per se. But each thinks that it needs to be expanded or enlarged so as to take alternative forms of political expression into account (see also Bohman 1995). Young, for example, argues that narrative or story-telling should be included since it can provide crucial insights into people's fears and aspirations, the motivations they attribute to others, and their willingness to act in some ways but not in others. Indeed, she claims that narrative 'is often the only vehicle for understanding the particular experiences of those in particular social situations, experiences not shared by those situated differently, but which they must understand in order to do justice' (Young 2000: 73-74).

Recently, a number of scholars have suggested that the sort of 'type I' approach that Rawls advocates and the sort of 'type II' approach that Sanders and Young advocate 'might be integrated in such a way as to complement each other' (Bachtiger et al. 2010: 34). In fact, Rawls allows that, on the 'wide view of public 
reason', people may appeal to their own beliefs and values, but only on the condition that, in due course, political values are presented to support their case (Rawls 1996: 1iii; 1997: 783-787). Narratives can enable groups to present a unified front, which may help them to get their views and concerns across to the wider public. But decisions about the basic structure of society cannot simply be based on narratives, not least of all because different narratives can conflict. When they do conflict, we must seek to deliberate from common ground or risk one group imposing its way of life on others (see Dryzek 2000: 68-69).

Nevertheless, while there are good reasons for privileging general political values, one might still worry that some people will struggle to couch their arguments in such terms. However, as we pointed out in our introductory remarks, the issue here is ultimately an empirical one: does who we are make a difference to our ability to deliberate in the way that Rawls suggests?

Table 1 below is based on our analysis of claims or (what we term) 'deliberative interventions' made in the field of ethnic relations in Britain, as reported in the pages of the The Guardian and the The Times. Formally, we define a deliberative intervention as a verbal statement made by an actor in the public sphere that rests upon a variable articulation of an argument in relation to the argument of another actor. More prosaically, an intervention usually takes the form of a direct quote and usually supports or opposes the views of some other actor. For example, defending his view that Imams should be trained at British universities to help Muslims integrate into mainstream society, the Prime Minister, Tony Blair, argued that 'The voices of extremism are no more representative of Islam than the use in times gone by of torture to force conversion to Christianity represented the teachings of Christ'. In response, Mazin Younis, a volunteer Imam at Leeds University, argued 
that 'Extremism is not created from abroad, it is coming from within. Blair's plans could have the opposite effect. 6 The coding of support and opposition allows us to map relations between actors and between actors and the values to which they appeal (which is central to the relational analysis that we present later).

Data are aggregated according to a number of broad categories of actor: for example, 'institutional actors' includes government, parliament and the judiciary, 'intermediate actors' includes political parties, trade unions and the media, 'minority actors' includes ethnic as well as various religious minorities such as Muslims, Jews and Sikhs, and 'civil society' includes NGO movements and general professional organisations. Data are also aggregated according to a number of broad categories of value: thus, 'civil and political liberties' includes human rights, freedom of religion and the good of democracy itself, 'justice' includes the right to a fair trial, fairness and equal treatment, 'safety, security and prosperity' includes peace, personal well-being and economic growth, 'respect for difference' includes empathy and mutual understanding, and 'social cohesion' includes inclusion, toleration and community.

Table 1 Actors and Values

\begin{tabular}{|l|l|l|l|l|l|}
\hline & $\begin{array}{l}\text { Institutional } \\
\text { actors \% }\end{array}$ & $\begin{array}{l}\text { Intermediate } \\
\text { actors \% }\end{array}$ & $\begin{array}{l}\text { Minority } \\
\text { actors \% }\end{array}$ & $\begin{array}{l}\text { Civil } \\
\text { society } \\
\text { actors \% }\end{array}$ & All actors \% \\
\hline No value & $12.6(33)$ & $14.7(10)$ & $10.0(11)$ & $9.0(16)$ & $11.3(70)$ \\
\hline $\begin{array}{l}\text { Civil and } \\
\text { political } \\
\text { liberties }\end{array}$ & $13.0(34)$ & $10.3(7)$ & $15.5(17)$ & $12.4(22)$ & $12.9(80)$ \\
\hline Justice & $15.6(41)$ & $13.2(9)$ & $13.6(15)$ & $17.4(31)$ & $15.5(96)$ \\
\hline $\begin{array}{l}\text { Safety, } \\
\text { security and } \\
\text { prosperity }\end{array}$ & $17.9(47)$ & $7.4(5)$ & $7.3(8)$ & $6.7(12)$ & $11.7(72)$ \\
\hline $\begin{array}{l}\text { Respect for } \\
\text { difference }\end{array}$ & $19.5(51)$ & $23.5(16)$ & $20.9(23)$ & $29.2(52)$ & $23.0(142)$ \\
\hline $\begin{array}{l}\text { Social } \\
\text { cohesion }\end{array}$ & $10.3(27)$ & $10.3(7)$ & $10.0(11)$ & $7.3(13)$ & $9.4(58)$ \\
\hline $\begin{array}{l}\text { Other } \\
\text { values }\end{array}$ & $11.1(29)$ & $20.6(14)$ & $22.7(25)$ & $18.0(32)$ & $16.2(100)$ \\
\hline Total & $100.0(262)$ & $100.0(68)$ & $100.0(110)$ & $100.0(178)$ & $100.0(618)$ \\
\hline
\end{tabular}


$N$ between parentheses

Cramer's $V=n s$

The first point to note is that this is not a 'top-down' elitist field in which institutional actors account for the vast majority of interventions. 'Bottom-up' intervention is strong and, in particular, minority actors are highly visible. The overall figure of 110 interventions for minorities goes well beyond that of 68 for intermediate actors. And when minorities are taken together with civil society, their visibility is actually higher than that of institutional actors. The second point to note is that minorities do not seem to have any difficulty appealing to the same values as everybody else. A quick glance at the data is sufficient to show that the situation in the field of ethnic relations in Britain is far from fostering 'internal exclusions of style and idiom', as Young suggests.

But what about the distribution of values across actors? The test of significance shows that there are no relevant differences in terms of the distribution of values between different categories of actor. Put simply, one can say that variations of value are not significantly linked to variations of actor. That said, disaggregating data does allow for some more specific remarks.

Take, for example, Muslims - a minority actor whose speech is supposedly particular rather than general. Our findings show that Muslims chiefly appeal to the value of social cohesion. But they also frequently appeal to 'other values', that is, to values that do not feature strongly in public political debate-for example, the need to increase moral standards, the importance of reputation and respect for animals. However, this latter characteristic is not all that unusual, since it is also shared with civil society actors.

While we recognise the provisional nature of these findings, and hence the need for further research in this area (for relevant contributions, see Wessler 2008; 
Dolezal et al. 2010), overall our data suggest that minorities do not struggle to couch their arguments in terms of general political values, or in terms of the sorts of value one might expect to find inherent in the public political culture of a modern democratic society. On the contrary, they seem to have relatively little trouble doing so.

\section{The challenge of value pluralism}

In our introductory remarks, we said that, to date, deliberative democrats have not had much to say about value pluralism. That may be because they have yet to see that value pluralism is potentially a problem or it may be because abstract theories are hard to translate into concrete empirical studies (if, indeed, they can sensibly be translated at all). But whatever the case, the truth of value pluralism would seriously impair the case for deliberative democracy. According to value pluralism, we can all agree that justice, equality, generosity, freedom, community, and so forth are genuinely valuable. Yet the trouble is that there is no uniquely right way of putting them together or of ranking them on a single scale (but see Dworkin 2006a). We are always having to make trade-offs and sacrifices and people make these in different ways.

If there is no uniquely right way of putting values together, there is little point in thinking that deliberative democracy might serve as a solution to value conflict. I might be able to appreciate your values and you might be able to appreciate mine. But should our values conflict, and should they also turn out to be uncombinable and incommensurable, there is no basis on which we might reason our way to a solution (cf. Bohman 1995: 254). Of course, not all conflicts are conflicts of value. Some are conflicts of interest, which might still be resolved through deliberation. But 
unfortunately some of the most pressing problems that we face today do involve conflicts of value, which is why the challenge here is so great.

Obviously, the truth of value pluralism would undermine Rawls's approach: although Rawls thinks that we should couch our arguments in terms of general political values, those values might well be uncombinable and incommensurable. But the truth of value pluralism would also undermine attempts to include narrative and other forms of political communication: the values which different narratives seek to express might be subject to the same problems as the values Rawls extols. (Naturally, the truth of value pluralism would also undermine attempts to integrate 'type I' and 'type II' approaches.)

Thus, in the somewhat dystopian words of John Finnis, 'if worldviews are incommensurable, we have no reason to accept a scheme of social decision making, a constitution, a Rule of Law. For each person, then, the challenge is simply to become and remain one of those who are in charge' (Finnis 1997: 217). Rather than accept such a conclusion, radical democrats such as William Connolly (2005), Chantal Mouffe (2002) and Glen Newey (2001) advocate a less overtly rational, more immanent, approach to dealing with conflicts of value. There are important differences between each of these thinkers, but for purposes of illustration, we can focus on the arguments of Connolly.

For Connolly, a 'pluralist' is someone who has his own beliefs and values but who also strives to accept, value and respect the positions of others. Thus, 'a pluralistic society inculcates the virtues of relational modesty between proponents of different faiths and creeds, and it seeks to limit the power of those who would overthrow diversity in the name of religious unitarianism' (Connolly 2005: 40-41). That view is similar to Rawls's idea of the good citizen who adheres to his own 
comprehensive doctrine but who, as a citizen, is also committed to others, with their different comprehensive doctrines, having the same part as himself in the political process. The difference is that Connolly thinks that pluralism will apply to all matters, including people's notion of the just or fair society. It is, therefore, a comprehensive doctrine of the sort that Rawls thinks should not be used to justify important decisions of law and policy.

The pluralism that Connolly adheres to is also different from 'value pluralism' as we find it in the works of, for example, Isaiah Berlin or John Gray. His pluralism is not simply a theory of value, but is also about recognising, embracing, valuing and providing for a world that is pluralist in nature. (That is, it is not just a meta-ethical theory but is also an ethical theory about how we ought to live.) It is not about overcoming conflict but about 'transmuting' 'antagonism' into 'agonism'. In particular, it is about generating 'agonistic respect' among people who hold different beliefs and values (Connolly 2005: 47-48).

Thus, Connolly not only accepts but positively celebrates (or would have us celebrate) the uncombinability and incommensurability of values. 'Agonistic respect' emerges not through democratic deliberation, but through the development of a 'relational sensibility'. That sensibility does not seek to place deliberative democracy 'above faith', but instead seeks 'to forge a positive ethos of public engagement between alternative faiths' (Connolly 2005: 49, 60). Agonistic respect works from within rather than from without.

Connolly advances a positive agenda — he thinks that uncombinability and incommesurability can be addressed through the cultivation of appropriate dispositions. Yet uncombinability and incommesurability are not themselves interrogated. By this we do not mean to suggest that they remain undefined. Rather, 
the problem is that Connolly simply assumes that different values are frequently incommensurable without every really testing that assumption.

As we have said, the truth of value pluralism would be extremely damaging for deliberative democracy: if value pluralism were true, conflicts of value could not be rationally arbitrated. But is it so?

\section{Assessing the truth of value pluralism}

One way in which we might proceed is to ask about value pluralism's explanatory power as a theory. The theory of gravity seems to do a pretty good job of explaining why things fall down. But does the theory of value pluralism do a good job of explaining value conflict — for example, a conflict between groups belonging to different religious faiths? According to Berlin, we 'are doomed to choose, and every choice may entail an irreparable loss' (Berlin 1991:13). But is that really how religious believers see things? Do they really think of themselves simply as having made different trade-offs and sacrifices? As Peter Jones argues, someone who is genuinely committed to a particular religious faith would be unlikely to accept that other faiths are no less valuable than his own. But if religious faiths really are incommensurable, that is indeed what he should accept (Jones 2006: 194). Since that seems implausible, it raises questions about the truth of value pluralism.

Rather than continue on this conceptual tack, let us instead proceed by considering whether the empirical evidence actually confirms or disconfirms the truth of value pluralism. In just a moment we will introduce our own data, but first we want to highlight some existing empirical research that bears on this question. 
Evidence from deliberative polls shows that deliberation consistently brings political preferences closer to 'single-peakedness' (Farrar et al. 2010). ${ }^{7}$ Simon Niemeyer and John Drzyek arrive at similar conclusions based on deliberative experiments using Q methodology (Niemeyer and Dryzek 2007). These findings are important because they suggest that deliberative democracy can bring people to understand an issue in the same way or along the same dimension. When there is more than one issue dimension, there is more than one social choice. But when there is only one issue dimension, decision making is much less arbitrary. ${ }^{8}$

This body of evidence does not show (nor does it claim to show) that deliberative democracy leads people to agree, only that they see what they disagree about so that there is an underlying dimension for their disagreement. In other words, it shows that deliberative democracy enables people to arrive at a meta-agreement on what the issues really are and what shared dimension underlies their differences (Fishkin 2009: 103-104). So it seems that deliberative democracy is not powerless in the face of value conflict: people may disagree, but deliberative democracy can at least bring them to understand the choice before them in the same way-including the values that ought to underpin their collective choice. ${ }^{9}$

The problem, however, is that this evidence does not refute the truth of value pluralism altogether. Deliberative democracy may lead people to agree that the policy options represent a choice between two values. For example, immigration policy, which might conceivably bring any number of values into play, might universally come to be seen as a choice between equal treatment and security. But those two values might still turn out to be uncombinable and incommensurable. At that point, deliberation might have run its course; there might be no possibility of reasoning with one another beyond that point (see Gray 1995b: 71). 
We accept that this may happen, but the vital question is to what degree? In order to get a handle on this question, we think that a relational analysis across actors and values is potentially a worthwhile research strategy. ${ }^{10}$ More specifically, a relational analysis allows us to do two things. First, it allows us to consider how different values are connected through the actors that make use of them. In this way, we can tackle the question of combinability; the higher the number of actors that appeal to a given pair of values, the more those values are combinable. Secondly, it allows us to compare patterns of exchanges that actors forge when referring to different values. In this way, we can tackle the question of commensurability: the more that values are rooted in similar relational patterns, the more they are commensurable. In both cases, we again draw on our data on ethnic relations in Britain.

Starting with combinability, table 2 presents a matrix of values by actors. Since the question we seek to answer is whether individual values are combinable, table 2 does not use aggregate categories of value as in table 1 but instead focuses on four specific political values — empathy, justice, equal opportunity and well-beingthat minorities use extensively. ${ }^{11}$ The number at the crossing of any two values indicates exactly how many different actors make use of the two values. The higher the number, the more likely it is that actors think of these values as being combinable.

Table 2. Combinability: values by actors

\begin{tabular}{|l|c|c|c|c|c|}
\hline & Empathy & Justice & $\begin{array}{c}\text { Equal } \\
\text { opportunity }\end{array}$ & Well-being & Total \\
\hline Empathy & $\mathrm{x}$ & 10 & 2 & 15 & 27 \\
\hline Justice & 10 & $\mathrm{x}$ & 4 & 8 & 22 \\
\hline $\begin{array}{l}\text { Equal } \\
\text { opportunity }\end{array}$ & 2 & 4 & $\mathrm{x}$ & 2 & 8 \\
\hline Well-being & 15 & 8 & 2 & $\mathrm{x}$ & 25 \\
\hline Total & 27 & 22 & 8 & 25 & \\
\hline
\end{tabular}


Scores show that values are combinable, since each possible pair is connected.

However, some values are more combinable than others: in terms of the numbers of actors who appeal to them, empathy and well-being are the most combinable whereas empathy and equal opportunity and well-being and equal opportunity are the least combinable. The other three possible pairs of values are somewhere in between.

Empathy is the most combinable overall, scoring a total of 27 links with all other values. By comparison, justice is less combinable than empathy, yet combines better with equal opportunity. Equal opportunity is the least combinable of the four, but is combinable nonetheless. So, while there is variation, scores do not not confirm the truth of value pluralism. Actors appeal to many different values and many different pairs of values.

Turning to the question of incommensurability, what needs to be considered is the extent to which values are too different to compare. We treat the degree to which values perform differently to one another as a valid indicator, with 'performance' defined in terms of the relational patterns that are built upon them. Hence, we ask: do values display the same relational pattern or do they display different relational patterns? The more that relational patterns differ, the more it may be that we are dealing with values that cannot be ranked along a single scale. In what follows, we analyse relational information for the same four political values as above. However, since we are interested in the patterns of exchanges that actors forge when referring to a given value, we are more explicit about the actors involved. ${ }^{12}$ In particular, since much of the ethnic relations debate in Britain focuses on Muslim actors (Muslims), we have treated these actors separately from other ethnic minority actors.

Figure 1 deals with the relational patterns that have been built upon the value of empathy. While the central position of governmental actors (Gov) is not a surprise, 
it is interesting to note that ethnic minority actors (EM) also have a fairly central position in the field. Although Muslim actors do not occupy a central position, they are directly linked to government and hence, via government, are well networked. Muslims are also closely linked to Hindus (Hindus) and, perhaps less surprisingly, to pro-minority organisations (Pro-M). More precisely, they act as a bridge bewteen Hindus and government and pro-minority organisations and government.

\section{Figure 1. Empathy: relational patterns}

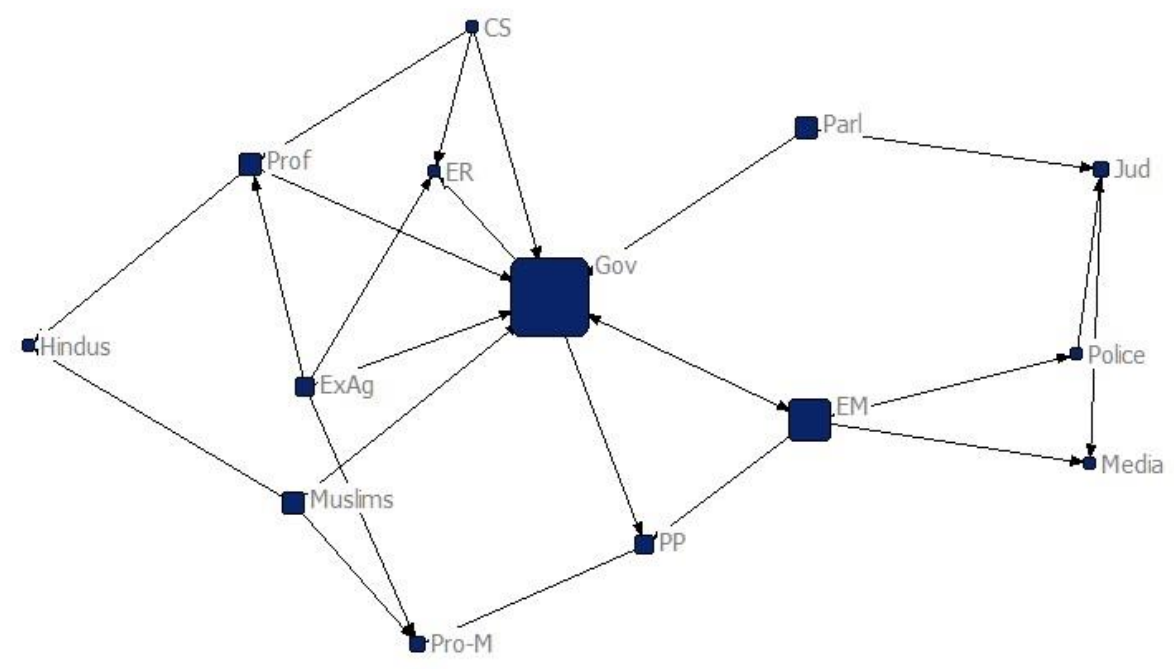

Figure 2 deals with relational patterns that have been built upon the value of well-being. In this case, ethnic minorities occupy a more peripheral position. While Muslims have forged ties with far fewer actors, they are once again closely linked to government and, as a consequence, enjoy an indirect link with every other actor in the field. In this respect, we can say that empathy and well-being perform similarly in relational terms. 


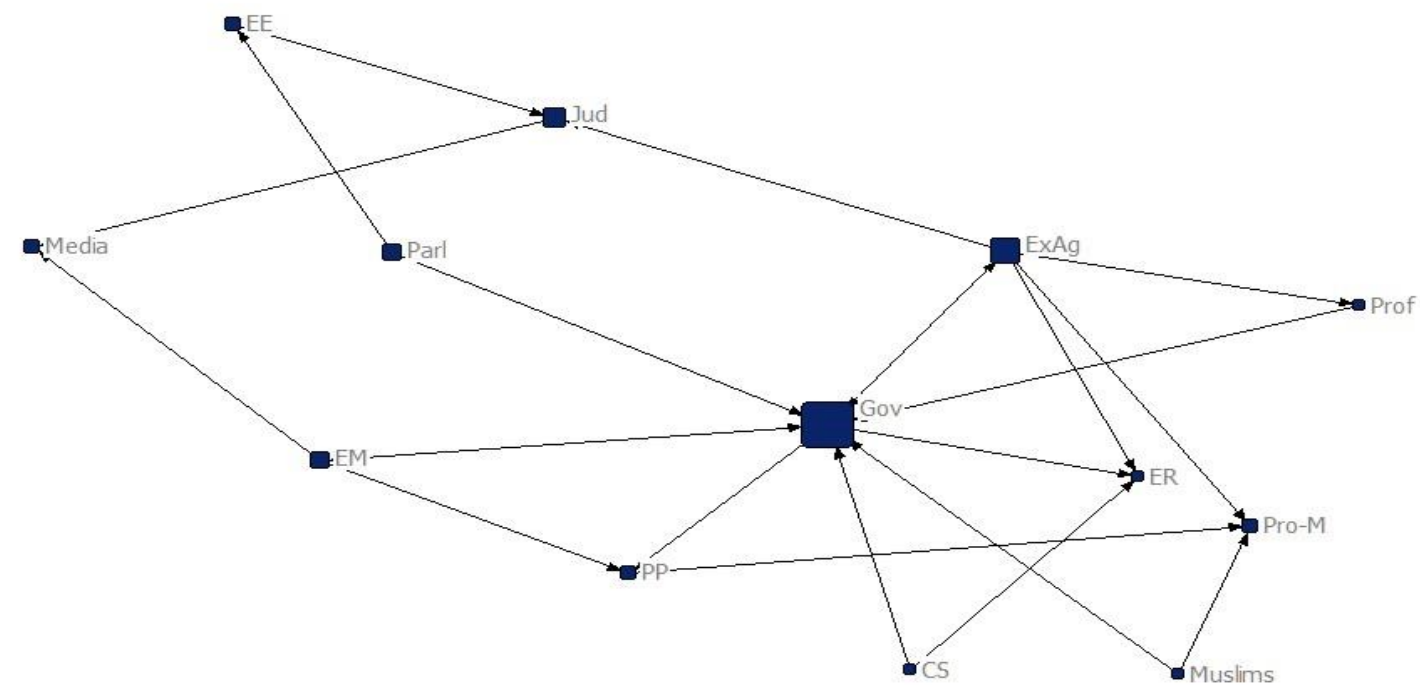

Moving to the analysis of 'justice' in figure 3, it is noticeable how this value performs similarly to empathy and well-being in terms of the concrete use that ethnic minorities make of it. Although quite peripheral, ethnic minorities are also present in the form of ethnic professional organisations (Ethprof) such as the National Black Police Association. However, Muslims do not feature in this relational field, appealing too rarely to the value of justice to be included in our analysis. To this extent, justice performs differently in relational terms to empathy and well-being.

\section{Figure 3. Justice: relational patterns}




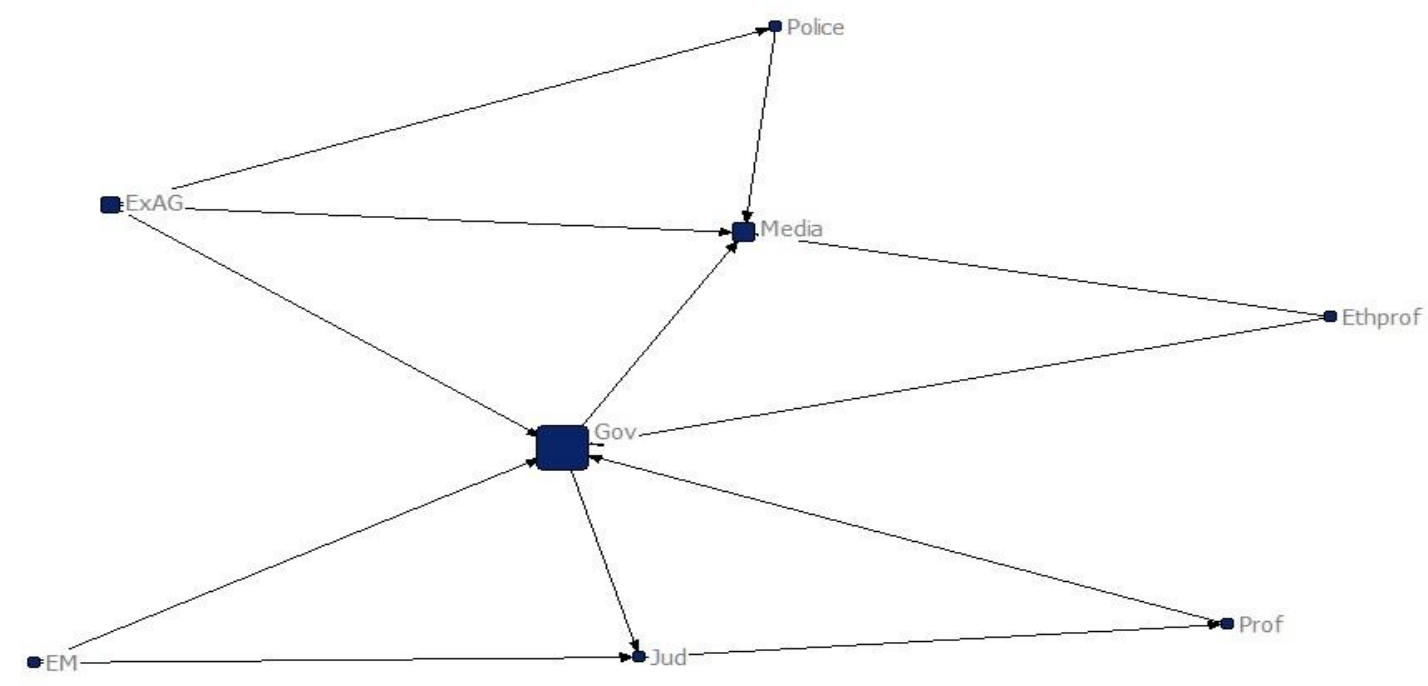

Figure 4 deals with our final value, 'equal opportunities'. Once again, Muslim actors have no role to play in this relation field. Yet unlike our other three values, ethnic professional organisations are highly central and are directly linked to three of the four actors of the relational field. Interestingly, this inverts the more usual pattern - unlike the other three values, government is peripheral rather than central and ethnic minorities are central rather than peripheral. Accordingly, this value performs very differently in relational terms to the other values we have examined.

Figure 4. Equal opportunities: relational patterns

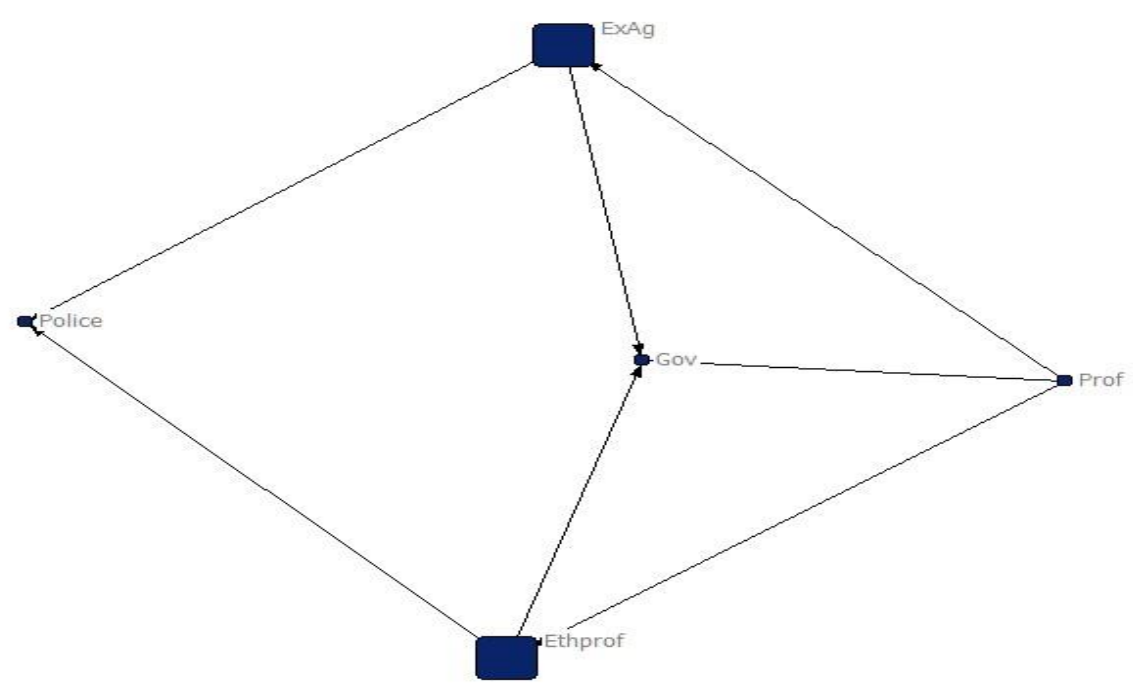


In sum, this evidence is fairly mixed. There is evidence of low levels of incommensurability — for example, the fact that government and executive agencies (ExAg) tend to offer a privileged axis of value discussion, the fact that Muslims are usually close to pro-minorities, and the consistent position of the police (Police). But there is also evidence of incommensurability—most obviously, equal opportunities seems to perform very differently, since it inverts the more usual pattern. Added to that, Muslims feature in only two of four relational fields, while the position of ethnic minorities is also variable (at times they are present in their own right and at times present only through the specific role of ethnic professionals).

It is hard to know what to say at this point. Part of the difficulty here is due to the fact that value pluralists themselves are undecided about just how much incommensurability value pluralism entails. So, whereas our evidence might conceivably count against the more extreme position held by John Gray, it might not count much against the more moderate position held by Isaiah Berlin. So really a lot depends on where one stands on the theoretical issues. That said, deliberative democrats need to spend time thinking not just about the philosophical issues, but also about questions of measurement. We have suggested that the extent to which actors fail to forge similar relational patterns upon different values might serve as an indicator of the incommensurability of those values. Yet we are happy to admit that there might be better, more telling, indictors to hand.

\section{Conclusion}


It is probably fair to say that, when deliberative democrats think about pluralism, they are thinking about the fact of pluralism. That fact is bound up with the question of how to respond to the fact that people not only differ but also disagree. We based our treatment of that question around a defence of Rawls's claim that arguments about important decisions of law and policy should be couched in terms of general political values - or the sorts of value that one might expect to find inherent in the public political culture of a modern democratic society. While that claim has come in for considerable criticism, we think that many of the criticisms are misplaced. General political values serve to ensure that one way of life cannot simply impose its beliefs and preferences on other ways of life. And while many deliberative democrats worry that the language of political values can itself have exclusionary effects, our empirical evidence does not support that worry.

The second half of this chapter considered the challenge that value pluralism poses to deliberative democracy. That challenge is bound up with a very different question: if values are uncombinable and incommensurable, is deliberative democracy powerless in the face of value conflict? Our evidence suggests that different values are, in fact, combinable, which gives the lie to value pluralism. We accept, though, that incommensurability is a harder nut to crack. We have tried to empirically assess how different values perform in terms of the different relational structures that are built upon them. The guiding thought here was that, insofar as values perform very differently, they are not comparable; they look different because they are different and hence it makes little sense to say that they can be ranked along a single scale. Here, the evidence neither confirms nor disconfirms the truth of value pluralism. What it does confirm, however, is the need for further research. 


\section{About the authors}

Manlio Cinalli, Centre de recherches politiques de Sciences Po (CEVIPOF), CNRS, 75007, Paris, France. E-mail: manlio.cinalli@ sciences-po.fr

Ian O’Flynn, School of Geography, Politics and Sociology, Newcastle University, Newcastle upon Tyne, NE1 7RU, UK. E-mail: ian.o'flynn@ncl.ac.uk

\section{Acknowledgement}

The authors are grateful to Peter Jones for extremely helpful comments on an earlier draft of this chapter.

\section{References}

Bachtiger, A., S. Niemeyer, M. Neblo, M. Steenbergen and J. Steiner (2010), 'Disentangling diversity in deliberative democracy: Competing theories, their blind spots and complementarities', Journal of Political Philosophy, 18:1, 3263.

Barry, B. (2006), 'Democracy needs dialogue and deliberation — not political blocs', in H. Afshar (ed.), Democracy and Islam, London: Hansard Society, pp. 2224.

Berlin, I. (1969), Four Essays on Liberty, Oxford: Oxford University Press. 
Berlin, I. (1991), The Crooked Timber of Humanity, London: Fontana.

Bohman, J. (1995), 'Public reason and cultural pluralism: Political liberalism and the problem of moral conflict', Political Theory, 23:2, 253-279.

Cinalli, M. and I. O’Flynn (2013). 'Public deliberation, network analysis and the political integration of Muslims in Britain', British Journal of Politics and International Relations, forthcoming.

Connolly, W. (2005), Pluralism, Durham: Duke University Press.

Crowder, G. (2002), Liberalism and Value Pluralism, London: Continuum.

Dolezal, M., M. Helbling and S. Hutter (2010) 'Debating Islam in Austria, Germany and Switzerland: Ethnic citizenship, church-state relations and right-wing populism', West European Politics, 33: 2, 171-190.

Dryzek, J. (2000), Deliberative Democracy and Beyond: Liberals, Critics, Contestations, Oxford: Oxford University Press.

Dworkin, R. (2006a), 'Moral pluralism' in R. Dworkin, Justice in Robes Cambridge: Harvard University Press, pp. 105-116. 
Dworkin, R. (2006b), Is Democracy Possible Here?: Principles for a New Political Debate, Princeton: Princeton University Press.

Farrar, C., J. Fishkin, D. P. Green, C. List, R. Luskin and E. L. Paluck (2010), 'Disaggregating deliberation's effects: An experiment within a deliberative poll', British Journal of Political Science, 40: 2, 333-347

Finnis, J. (1997), 'Communsuration and public reason' in R. Chang (ed.), Incommensurability, Incomparability and Practical Reason, Cambridge: Harvard University Press, pp. 215-233.

Fishkin, J. (2009), When the People Speak: Deliberative Democracy and Public Consultation, Oxford: Oxford University Press.

Gray, J. (1995a), Enlightenment's Wake: Politics and Culture at the Close of the Modern Age, London: Routledge.

Gray, J. (1995b), Isaiah Berlin, London: Fontana.

Gray, J. (2000), Two Faces of Liberalism, Cambridge: Polity.

Habermas, J. (1998), 'Reconciliation through the public use of reason', in C. Cronin and P. De Greiff (eds), The Inclusion of the Other, Cambridge: Polity Press, pp. 49-73. 
Jones, P. (2003), 'Toleration and neutrality: Compatible ideals?', in D. Castiglione and C. McKinnon (eds), Toleration, Neutrality and Democracy Dordrecht: Kluwer, pp. 97-110.

Jones, P. (2006), 'Toleration, value-pluralism and the fact of pluralism', Critical Review of International Social and Political Philosophy, 9; 2, 189-210.

Knoke, D. and J. Kuklinsky (1982), Network Analysis, London: Sage.

Koopmans, R. and P. Statham (1999), 'Political claims analysis: Integrating protest event and political discourse approaches', Mobilization, 4: 2, 203-222.

Lassman, P. (2011), Pluralism, Cambridge: Polity.

Mackie, G. (2003), Democracy Defended, Cambridge: Cambridge University Press.

Maxwell, R. (2006), 'Muslims, South Asians and the British mainstream: A national identity crisis?', West European Politics, 29: 4, 736-756.

McQuail, D. (1992), Media Performance: Mass Communication and the Public Interest, London: Sage.

Meer, N. (2006), “"Get off your knees”: Print media public intellectuals and Muslims in Britain', Journalism Studies, 7:1, 35-59. 
Miller, D. (1992), 'Deliberative democracy and social choice', Political Studies, 40 (issue supplement), 54-76.

Mouffe, C. (1999), 'Deliberative democracy of agonistic pluralism?', Social Research, 66: 3, 745-758.

Newey, G. (2001), After Politics: the Rejection of Politics in Contemporary Liberal Philosophy, Basingstoke: Palgrave Macmillan.

Niemeyer, S. and J. Dryzek (2007), 'The ends of deliberation: Meta-consensus and inter-subjective rationality as ideal outcomes', Swiss Political Science Review, 13: 4, 497-526.

Peters, B., T. Schultz and A. Wimmel (2008), 'Contemporary journalism and its contribution to a discursive public sphere', in H. Wessler (ed.), Public Deliberation and Public Culture: The writings of Bernhard Peters, 1993-2005, Basingstoke: Palgrave Macmillan, pp. 134-59

Rawls, J. (1996), Political Liberalism, $2^{\text {nd }}$ ed., New York: Columbia University Press.

Rawls, J. (1997), 'The idea of public reason revisited', The University of Chicago Law Review, 64: 3, 765-807.

Sanders, L. (1997), 'Against deliberation', Political Theory, 25: 3, 347-376.

Scott, J. (2000), Social Network Analysis: A Handbook, London: Sage. 
van Mill, D. (1996), 'The possibility of rational outcomes from democratic discourse and procedures', The Journal of Political, 53: 3, 734-752.

Wasserman, S. and K. Faust (1994), Social Network Analysis: Methods and Applications, Cambridge: Cambridge University Press.

Wessler, H. (2008), 'Investigating deliberativeness comparatively', Political Communication, 25: 1, 1-22.

Young, I. M. (2000), Inclusion and Democracy, Oxford: Oxford University Press.

\footnotetext{
${ }^{1}$ We accept that newspapers are always subject to problems of selection bias and hence to the risk of portraying a distorted deliberative reality (e.g., McQuail 1992: 193-195). Yet the fact remains that newspaper reporting plays its part in constituting the world in which we live and, in effect, determining and delimiting the scope for deliberative democracy. In short, one 'does not need to adhere to the fashion for radical constructivism and post-modernism to recognise that the mass media contribute to the symbolic construction of realities' (Peters et al. 2008: 139). ${ }^{2}$ See e.g., Berlin 1969, 1991; Gray 1995a, 1995b, 2000; but see Dworkin 2006a; Jones 2006.

${ }^{3}$ On network analysis, see Wasserman and Faust 1994; Knoke and Kuklinsky 1982; Scott 2000 .
} 
${ }^{4}$ In Political Liberalism (1996: 57), Rawls does make a favourable comment in relation to Isaiah Berlin. In particular, he accepts Berlin's point that hard choices sometimes need to be made between values. Yet that does not commit him to value pluralism. On the contrary, he explicitly dissociates himself from that theory (1996: 57, n. 10). As far as we know, Rawls never makes any use of, or even refers to, uncombinability or incommensurability.

${ }^{5}$ In a similar vein, Ronald Dworkin has recently argued that, despite appearances to the contrary, most Americans, whether 'red' or 'blue' in ideological conviction, share a basic commitment to the values of intrinsic equality and personal autonomy (Dworkin 2006b). He then goes on to show how those values can serve as common ground on which to deliberate about some of the most divisive issues in American public policy (abortion, health care etc.).

${ }^{6}$ In our analysis, actors deliberate (or are classed as deliberating with one another) only when they argue back forth over a repeated number of instances (a single deliberative intervention would not capture the dynamic nature of deliberation as we understand it). We take three such exchanges as the minimum required for there to be deliberation. In the example cited in the text, Blair was coded as 'government' and Younis as 'Muslim'.

7 'A combination of preferences is single-peaked across individuals if the alternatives can be aligned on some "structuring" dimension, say from left to right, such that every individual has a most preferred alternative and a decreasing preference for other alternatives as they get more distant in either direction from it' (Farrar et al. 2010: 337-338). 
${ }^{8}$ For an early formulation, see Miller 1992. For a more extensive study of this and related issues, see Mackie 2003. For a summary of the social choice critique of deliberative democracy, see van Mill 1996: 740-743.

${ }^{9}$ To date, the mechanisms by which all of this works are open to debate. How exactly is it that deliberation leads people in the direction of uni-dimensionality? Miller argues that having to deliberate in public will automatically exclude certain sorts of argument and preference, specifically those that appeal to or reflect purely private interests (Miller 1992: 61-62). Fishkin points to the effects of balanced argument and good information on the preferences people hold (Fishkin 2009: 34). Niemeyer and Dryzek stress the importance of logical consistency or what they term 'intersubjective rationality' (Niemeyer and Dryzek 2007: 50).

${ }^{10}$ Methodologically, we draw on network analysis. See note 3 above.

11 The thought here is that values that are notable for the fact that are used extensively by minority actors will be less combinable overall than values notable for the fact that they are extensively used by majority actors. In other words, the thought is that they provide a sterner test. Whether this is actually the case is in need of further testing. ${ }^{12}$ In figures 1-4, actors are as follows: CS = civil society organisations; EE = ethnic extremists; $\mathrm{EM}=$ ethnic minorities; $\mathrm{ER}=$ extreme right; Ethprof = ethnic professional organisations; ExAg = executive agencies; Gov = government; Hindus = Hindus; Jud $=$ the judiciary $;$ Media $=$ media $;$ Muslims $=$ Muslims $;$ Police $=$ police $;$ Parl $=$ parliament PP = political parties; Prof = professional bodies; Pro-M = pro-minority organisations. 